Review Article

\title{
Phytochemicals, Pharmacological Properties and Biotechnological Aspects of Highly Medicinal Plant: Datura stramonium
}

\author{
Aamana Batool, Zahra Batool, Rahmatullah Qureshi, Naveed Iqbal Raja \\ Department of Botany, Faculty of Sciences, Pir Mehr Ali Shah Arid Agriculture University Rawalpindi, Rawalpindi, Pakistan
}

\section{Email address:}

amna4340arid@gmail.com (A. Batool),zahrabatool@yahoo.com (Z. Batool), rahmatullahq@uaar.edu.pk (R. Qureshi), drnaveedraja@gmail.com (N. I. Raja)

\section{To cite this article:}

Aamana Batool, Zahra Batool, Rahmatullah Qureshi, Naveed Iqbal Raja. Phytochemicals, Pharmacological Properties and Biotechnological Aspects of Highly Medicinal Plant: Datura stramonium. Journal of Plant Sciences. Vol. 8, No. 2, 2020, pp. 29-40. doi: $10.11648 /$ j.jps.20200802.12

Received: June 20, 2016; Accepted: March 31, 2020; Published: April 28, 2020

\begin{abstract}
Plants are the backbone of the life on earth. They are essential resource for human well- being and among them Datura stramonium is one of highly important plants commonly known as Jimson weed. It is an annual herb found in temperate and sub-tropical areas. Its medicinal significance is mainly because of higher amounts of tropane alkaloids and traditionally used throughout the world. It possesses many phytoconstituents including alkaloids, flavonoids, amino acids, tannins, saponins, carbohydrates, terpenoids, steroidal glycosides and phenols. Various pharmacological activities i.e. anti-asthmatic, antimicrobial, antioxidant, anticancer and anti-inflammatory are exhibited by the plant. Secondary metabolites obtained from species of Datura genus produce tropane alkaloids which have influence on human nervous system and are used in medicines. Despite of its medicinal importance it is a potentially poisonous plant and known as plant hallucinogen. Its random use can cause restlessness and acute poisoning may lead to death. In global increasing energy demand scenario, Datura stramonium plant seeds oil is proved as an efficient source for biodiesel production. This paper will present an exclusive review with respect to the phytochemicals, ethno-medicinal, pharmacological and biotechnological aspects which will lay a solid foundation for further scientific research work to exploit the medicinal and industrial benefits of this plant.
\end{abstract}

Keywords: Datura stramonium, Jimson Weed, Tropane Alkaloids, Phytochemicals, Pharmacology, Biotechnology

\section{Introduction}

All over the world Datura stramonium is known to be a very important medicinal plant and hallucinogen. The various parts of the plant i.e. flowers, leaves, seeds and roots are used in many medical treatments so Datura stramoniumhas a very special place in Ayurveda. The plant Datura stramonium L. belongs to genus Datura and family Solanaceae. The word Datura is derived from Sanskrit word Dhutra which means "divine inebriation". It is a local plant of North America it was identified and scientifically described by a Swedish botanist Carl Linnaeus in 1753 [54, 59]. Datura stramonium is cosmopolitan plant found in many plant communities [86].
Datura stramonium is an annual herb and its height could be upto 2-5 feet $(60-120 \mathrm{~cm})$, it is erect and has foul smell [73]. Many species of Datura are used very extensively because of their medicinal values as it contains more than 30 alkaloids [74]. Since 1925 for isolation and identification of total alkaloid contents in Datura a lot of researches are carried out and the phytochemical constituents of plant are scopolamine, atropine, hyoscyamine, and tropanes [6, 9]. In Ayurveda the parts of the plant are used for curing skin disorders, asthma, jaundice, piles and diabetes [14]. It has antifungal, antibacterial, antiulcer, antispasmodic, larvicidal, antioxidant [12], antinociceptive [1], hypolipidemic [62], hypoglycemic and anti-rheumatoid [26] activities and used in traditional folklore medicine in the world. 


\subsection{Common Names}

Stace [77] reported the following common names of plant:

English Name: Thorn apple, Devil's trumpet

Hindi Name: Sadadhatura

Tamil Name: Ummattangani

Telugu Name: Ummetta

Bengal Name: Dhattura

Gujrati Name: Dhattura

Marrathi Name: Dhattura

Kannada Name: Anmatta

Malayalam Name: Anmatta

Arabic Name: Datur

Persian Name: Tatur

Spanish name: Estramonio

\subsection{Classification}

Soni et al., [75] proposed the following classification of plant.

Kingdom: Plantae

Division: Magnoliophyta

Class: Magnoliopsida

Order: Solanales

Family: Solanacaeae

Genus: Datura

Species: Datura stramonium

\section{Method}

The literature about the description, distribution, phytoconstituents, pharmacology, traditional uses and toxicity of Datura stramonium was collected from online bibliographic databases and libraries. The sources of information include Elsevier, Research gate, Hindawi, Wiley-Blackwell, Google scholar, Science direct, PubMed and Springer link.

\section{Botanical Description}

Datura stramonium is considered as an annual herb and its stem is characterized as herbaceous, glabrous, leafy erect smooth and branched stem having very few hairs and its color is pale yellowish green. The plant possess simple leaves which are big in size, ovate, their margins are dentate, petiolate, leaves are 4-6 inch long, they also possess hair. The color of upper surface of leaves is grayish green and it is smooth, whereas the lower surface possesses wrinkles and it is pale green in color [64]. The flower is about 3 inches in length with long and tubular calyx and funnel shaped corolla. The color of flower is white or purple, the number of stamens is five and the ovary is superior. It contains smooth, black and kidney shaped seeds in a very big and thorny fruit [79]. The approximate height of the plant is about one [3, 31, 32]. The height of the plant is 2-4 feet and its diameter could be 4-6 feet. It has very large flowers and the length of corollas is $6 \mathrm{~cm}$. The leaves are $20 \mathrm{~cm}$ long and they have coarsely dentate margins. The root is thick, tapering and branched. It is estimated that under favorable conditions typically 14,964 seeds are present in each plant [58].

\section{Distribution}

The origin of Datura stramonium is uncertain [13]. It is locally found in the areas of tropical climates such as India, Mexico, and South America [88]. It is found in the garbage dumps in the Europe [59]. It was brought in UK from various resources such as soybean waste and bird seed [69, 73]. Jimson weed is the native plant of the most of temperate and subtropical areas so it is most probably originated in Central America. Although Datura stramonium is originated in America but it is commonly found in the cultivated fields of France [36].

Jimson weed is indigenously found in Middle East, Germany, France, United States, South America, Capsian region and Hungary [81]. Thorn apple is widely distributed in the temperate regions of the world [6]. In UK Jimson weed is infrequently found especially during the hot summers. Datura stramonium is found on most of the places as a weed ranging from roadsides to farm in India [74]. The plant is present in the gardens, pastures and wastelands of district Baghdad [3]. It is not only a native plant of South Africa but it is also found in many other parts of the world as it was used by Red Indians for a long period of time as euphoric agent, and it is also utilized as therapeutic agent in the great Britain since 1800's [82].

\section{Phytochemicals}

The alkaloid content of Datura stramonium is $0.27 \%$ [6]. It contains apohyoscine, meteloidineas well as hyoscine and atropine [15]. There are various minor alkaloids i.e. tigloidin, aposcopolamine, atropine, hyoscyamine, apoatropine, hyoscyamine N-oxide, Scopolamine N-oxide, 6 $\alpha$-ditiglyoyloxytropane and 7- hydroxyhyoscyamine [14, 79]. The phytochemical screening of jimson weed seeds reveals that it contains alkaloids, flavonoids, amino acids, tannins, saponins, carbohydrates, phenols, glycosides, steroids and terpenoids $[53,21]$. They also have isolectins, two of them are homodimers having subunits $\mathrm{A}$ and $\mathrm{B}$, while one of them is heterodimer. Among the members of the family Solanaceae the plant Datura stramonium is highly important because it is a great source of tropane alkaloids (atropine, hyoscyamine and scopolamine). The leaves and seeds of the plant contain very high amounts of alkaloids such as atropine, scopolamine and hyoscyamine and these compounds have anticholinergic activities and therefore they are the constituents of most of the official pharmacopoeias [51, 87]. The investigation of ethanolic extracts of leaves of thorn apple by the use of gas chromatography -mass spectroscopy techniques indicated the presence of Ethyl iso-allocholate, D-asycarpidan-1-methanol, acetate (ester); 3- (1, 5-Dimethyl-hexyl) 3a, 101, 10, 12b tetramethyl 1, 2, 3, 3a, 4, 6, 8, 9, 10, 10, 12a, 12b tetradecahydro benzo $(4,5)$ cyclohept, 2,7 - dipheny 1 - 1, 6 dioxopyridazino $(4,5,2,3)$ pyrrole $(4,5-\mathrm{d})$ pyridazine; 3,8 , 8 - trimethoxy -3 - piperidy $1-2,2$ - benaphthalene $-1,1,4$, 4 - tetrone; (5 $\beta$ ) pregnane $3,20 \beta$ - diol, $14 \alpha, 18 \alpha-(1-$ oxa - 
4 - azabutane - 1, 4 -diy 1), diacetate; 1 monolinoleoglycerol trimethylsilylether and 17 - (1, 5 dimethylhexyl) - $10,13-$ dimethyl $1-3-$ strylhexadecahydrocyclopenta [a] phenathren - 2 - one [3]. These phytocompounds have antimicrobial and anti-oxidant properties [43, 45, 67, 68, 73, 84]. The phytochemicals present in the leaves of Datura stramonium include proteins, carbohydrates, glycosides, alkaloids, steroids, phenol, terpenoids [17]. There are sixty seven alkaloids found in Datura stramonium. Nine new tropane alkaloids $6,7-$ dehydroxy - 3 - tigloyloxytropane; 3, 7 - dihydroxy - 6 - (2' - methlybutyryloxy) tropane; 3, 7 - dihydroxy - 6 propionyloxytropane; $3 \beta$-tropoyloxy- $6 \beta$-isovaleroxytropane; 3 - tigloyloxy -6 is obutyryloxy -7 - hydroxytropane; 6, 7 dehydroapoatropine; 6,7 - dehydroxy -3 - tigloyloxytropane; 3 - (3' - methoxytropoyloxy) tropane; $3 \beta$-tropoyloxy - $6 \beta$ isovaleroxytropane; 3 - tigloyloxy -6 isobutyryloxy -7 hydroxytropane; 3 - hydroxyl - 6 - (2' - methylbutyryloxy) tropane; 3 - tigloyloxy - 6, 7 - epoxytropanes have been identified in Datura stramonium plant and among them 4-hydroxylittorine; cyclotropine; dihydroxyaposcopolamine, 6, 7 - dehydroxyhyoscyamine are the compounds which are for the first time identified in the genus Datura and 6, 7-dehydrotropine is first time identified in the Solanaceae family $[2,22]$. The seeds of the plant contain high amounts of fat, fibers and carbohydrates along with phytate, tannin and oxalate. Tropane alkaloid, phytic acids, amino acids, tannins and carbohydrates can be isolated from Datura stramonium. There are $0.2-0.6 \%$ alkaloids in this plant. It contains albumin and atropine but the main alkaloids are hyoscyamine and hyoscine (scopolamine) and the usual proportion of these chemicals is approximately two parts of hyoscyamine and one part hyoscine where as in young plants the hyoscine is predominant component [22]. The phytochemicals found in the roots are ditiglyol esters of 3, 6 dihydroxytropane and 3, 6, 7 -trihydroxytropane, hyoscyaminendhyoscine as well as pseudotropine. In addition to 6-hydroxyscymine, skimmianine, metelodine, acetylderivatives of caffiec, p-coumaric, ferulic acid, campesterol, stigmasterol, anolide 1, steroidal glycosides, daturataturins, flavanoids, chrysins and quercitin. The seeds cotain wax, resin oils, gummy material and malic acid. Another important phytochemical is withastramonolide $[5,8$, $9,11,18,22,23,40,49,55,56,57,63,65,78]$. Daturic acid has been isolated from the seeds of datura. The alkaloids found in the seeds of the plant are N-tranferulyl tryptamine, hyoscyamilactol, scopoletin, umckalin, daturaolone, $\mathrm{N}$-transferulicacyl tyramine, cleomiscosin, fraxetin [56].

Table 1. Chemical compounds found in Datura stramonium.

\begin{tabular}{|c|c|c|c|}
\hline SR. NO & COMPOUNDS & SOURCES & REFERENCES \\
\hline 1 & 3-acetoxytropane & $\mathrm{R}, \mathrm{ST}$ & [89] \\
\hline 2 & 3-acetoxytropane-6-isobutyryloxytropane & $\mathrm{R}, \mathrm{ST}, \mathrm{L}, \mathrm{P}$ & [49] \\
\hline 3 & $3 \alpha$-apotropoyloxytropane & $\mathrm{R}, \mathrm{L}, \mathrm{ST}$ & [11] \\
\hline 4 & $3 \beta$-apotropoyloxytropane & $\mathrm{S}$ & {$[11]$} \\
\hline 5 & Aponorscopolamine & ST, L, P & {$[22]$} \\
\hline 6 & Aposcopolamine & $\mathrm{R}, \mathrm{ST}, \mathrm{L}, \mathrm{P}, \mathrm{S}$ & [89] \\
\hline 7 & 3-(3-acetoxytropoyloxy) tropane & $\mathrm{R}, \mathrm{ST}, \mathrm{L}$ & {$[56]$} \\
\hline 9 & 3, 6-diacetoxytropane & $\mathrm{R}$ & {$[57]$} \\
\hline 10 & 3, 7-dihydroxy-6-tigloyloxytropane & $\mathrm{S}$ & {$[22]$} \\
\hline 11 & $3 \alpha, 6 \beta$-ditiglyoloxytropane & $\mathrm{R}, \mathrm{ST}$ & {$[40]$} \\
\hline 12 & $3 \beta, 6 \beta$-ditiglyoloxytropane & $\mathrm{R}$ & {$[40]$} \\
\hline 13 & $3 \alpha, 6 \beta$-ditiglyoloxy-7-hydroxytropane & $\mathrm{R}, \mathrm{ST}$ & [89] \\
\hline 14 & $3 \beta, 6 \beta$-ditiglyoloxy-7-hydroxytropane & $\mathrm{R}$ & {$[56]$} \\
\hline 15 & 3, 6-disubstitutedtropanes & $\mathrm{R}, \mathrm{ST}$ & {$[40]$} \\
\hline 18 & 3, 7-dihydroxy-6- (2'-methlybutyryloxy) tropane & Plant & {$[5]$} \\
\hline 19 & 6,7 -dehydroapoatropine & Plant & {$[5]$} \\
\hline 20 & Hygrine & ST & [89] \\
\hline 21 & 3- (hydroxyacetoxy) tropane & $\mathrm{ST}, \mathrm{R}$ & {$[63]$} \\
\hline 22 & 6- hydroxyacetoxytropane & $\mathrm{R}$ & {$[40]$} \\
\hline 23 & 3-hydroxy-6-acetoxytropane & $\mathrm{R}, \mathrm{ST}$ & {$[57]$} \\
\hline 24 & 3-hydroxy-6- (2-methylbutyryloxy) tropane & $\mathrm{L}$ & [89] \\
\hline 25 & 3-hydroxy-6-tigloyloxytropane & $\mathrm{R}, \mathrm{ST}, \mathrm{L}, \mathrm{P}$ & [89] \\
\hline 26 & Hyoscyamine & $\mathrm{R}, \mathrm{ST}, \mathrm{L}, \mathrm{S}$ & [89] \\
\hline 27 & 6-hydroxyapoatropine & $\mathrm{R}, \mathrm{ST}, \mathrm{L}$ & {$[40]$} \\
\hline 28 & 7-hydroxyhyoscyamine & ST, L & {$[5]$} \\
\hline 29 & 6-hydroxyhyoscyamine & $\mathrm{R}, \mathrm{ST}, \mathrm{L}$ & [40] \\
\hline 30 & Littorine & $\mathrm{R}, \mathrm{ST}, \mathrm{L}, \mathrm{S}$ & [63] \\
\hline 31 & Meteloidine & $\mathrm{R}, \mathrm{P}$ & [89] \\
\hline 32 & 3-monosubstitutedtropanes & $\mathrm{R}, \mathrm{L}$ & {$[40,89]$} \\
\hline 35 & Phenylacetoxytropane & $\mathrm{R}, \mathrm{ST}, \mathrm{L}, \mathrm{S}$ & {$[40]$} \\
\hline 36 & 3-phenylacetoxy-6, 7-epoxytropane & $\mathrm{R}, \mathrm{ST}, \mathrm{L}, \mathrm{P}$ & {$[85]$} \\
\hline
\end{tabular}




\begin{tabular}{|c|c|c|c|}
\hline SR. NO & COMPOUNDS & SOURCES & REFERENCES \\
\hline 37 & 3- (2'phenylpropionyloxy) tropane & $\mathrm{L}$ & {$[18]$} \\
\hline 38 & 3-phenylacetoxy-6-hydroxytropane & $\mathrm{R}, \mathrm{ST}$ & {$[63]$} \\
\hline 39 & $3 \alpha$-phenylacetoxytropane & $\mathrm{S}$ & {$[49]$} \\
\hline 40 & $3 \beta$-phenylacetoxytropane & $\mathrm{S}$ & {$[11]$} \\
\hline 41 & Scopoline & $\mathrm{S}, \mathrm{L}, \mathrm{ST}, \mathrm{P}$ & {$[40]$} \\
\hline 42 & Scopine & $\mathrm{L}, \mathrm{P}, \mathrm{S}$ & {$[40]$} \\
\hline 43 & Scopolamine & $\mathrm{R}, \mathrm{ST}, \mathrm{L}, \mathrm{P}$ & {$[8]$} \\
\hline 44 & 3-substituted-6, 7-epoxytropanes & $\mathrm{R}, \mathrm{P}, \mathrm{ST}, \mathrm{S}$ & {$[40,89]$} \\
\hline 45 & Tropinone & $\mathrm{S}$ & [40] \\
\hline 46 & $3 \alpha$-tigloyloxytropane & ST. R & [89] \\
\hline 47 & $3 \beta$-tigloyloxytropane & $\mathrm{R}$ & [89] \\
\hline 48 & $3 \alpha$-tigloyloxy-6-hydroxytropane & $\mathrm{R}, \mathrm{ST}$ & [89] \\
\hline 49 & $3 \beta$-tigloyloxy-6-hydroxytropane & $\mathrm{R}$ & [89] \\
\hline 50 & 3 -tigloyloxy-6-acetoxytropane & $\mathrm{R}$ & [89] \\
\hline 51 & 3-tigloyloxy-6-propionyloxy-7-hydroxytropane & $\mathrm{R}, \mathrm{ST}, \mathrm{L}, \mathrm{P}$ & {$[8]$} \\
\hline 52 & 3-tigloyloxy-6-propionyloxytropane & $\mathrm{R}$ & [89] \\
\hline 53 & 3-tigloyloxy-6-isobutyryloxytropane & $\mathrm{R}$ & [89] \\
\hline 54 & 3-tigloyloxy-6- (2-methylbutyryloxy) tropane & $\mathrm{R}, \mathrm{ST}$ & [89] \\
\hline 55 & 3-tigloyloxy-2-methylbutyryloxytropane & $\mathrm{R}$ & [89] \\
\hline 56 & $3 \alpha$-tigloyloxy-6-isovaleryloxy-7-hydroxytropane & $\mathrm{R}$ & {$[49,65]$} \\
\hline 57 & $3 \beta$-tigloyloxy-6-isovaleryloxy-7-hydroxytropane & $\mathrm{R}$ & {$[49,65]$} \\
\hline 58 & 3-tropoyloxy-6-acetoxytropane & $\mathrm{R}, \mathrm{ST}$ & {$[8]$} \\
\hline 59 & 3, 6, 7-trisubstitutedtropanes & ST, L & {$[40,89]$} \\
\hline 60 & Tropine & $\mathrm{R}, \mathrm{ST}, \mathrm{L}, \mathrm{S}$ & {$[40]$} \\
\hline 61 & 3-tigloyloxy-6, 7-dihydroxytropane & $\mathrm{R}$ & [11] \\
\hline 62 & 3-tigloyloxy-6-methylbutyryloxytropane & $\mathrm{R}$ & [89] \\
\hline 63 & 3 -tropoyloxytropane & $\mathrm{R}, \mathrm{L}, \mathrm{S}$ & {$[11]$} \\
\hline 64 & 3-tropoyloxy-6, 7-epoxynortropane & $\mathrm{R}$ & {$[11]$} \\
\hline 65 & 3-tropoyloxy-6, 7-epoxytropane & $\mathrm{R}, \mathrm{L}, \mathrm{S}$ & {$[11]$} \\
\hline 66 & 3 -tropoyloxy-6-hydroxytropane & $\mathrm{R}$ & {$[42]$} \\
\hline 67 & 3-tropoyloxy-6-tigloyloxytropane & $\mathrm{R}$ & {$[11]$} \\
\hline 68 & 3-tigloyloxy-6, 7-epoxytropane & Plant & {$[5]$} \\
\hline 69 & 3-tigloyloxy-6 isobutyryloxy-7-hydroxytropane & Plant & {$[5]$} \\
\hline 70 & 3-tropoyloxy-6-isobutyryloxytropane & Plant & {$[5]$} \\
\hline 71 & $3 \beta$-tropoyloxy- $6 \beta$-isovaleroxytropane & Plant & [5] \\
\hline
\end{tabular}

L: Leaves, R: Roots, S: Seeds, ST: Stem, P: Pericarp

Table 2. Phytochemicals found in leaves of datura stramonium [3, 5].

\begin{tabular}{|c|c|c|c|}
\hline $\begin{array}{l}\text { SR. } \\
\text { NO }\end{array}$ & ALKALOID COMPOUND & FORMULA & $\begin{array}{l}\text { MOLECULAR } \\
\text { WEIGHT }\end{array}$ \\
\hline 1 & Ethyl iso-allocholate & $\mathrm{C}_{26} \mathrm{H}_{44} \mathrm{O}_{5}$ & 436 \\
\hline 2 & D-asycarpidan-1-methanol, acetate (ester) & $\mathrm{C}_{20} \mathrm{H}_{26} \mathrm{~N}_{2} \mathrm{O}_{2}$ & 326 \\
\hline 3 & $\begin{array}{l}\text { 3-(1, 5-Dimethyl-hexyl) 3a, 101, 10, 12b-tetramethyl 1, 2, 3.3a, 4, 6, 8, 9, 10, 10, 12a, } \\
\text { 12b-tetradecahydro-benzo }[4,5] \text { cyclohept }\end{array}$ & $\mathrm{C}_{30} \mathrm{H}_{50}$ & 410 \\
\hline 4 & 2,7 - diphenyl-1, 6 - dioxopyridazino $[4,5: 2,3]$ pyrrole $[4,5$ - d] pyridazine & $\mathrm{C}_{20} \mathrm{H}_{13} \mathrm{~N}_{5} \mathrm{O}_{2}$ & 355 \\
\hline 5 & 3, 8, 8-trimethoxy-3-piperidyl-2, 2- benaphthalene-1, 1, 4, 4-tetrone & $\mathrm{C}_{28} \mathrm{H}_{25} \mathrm{NO}_{7}$ & 487 \\
\hline 6 & [5 $\beta$ ] pregnane 3, $20 \beta$-diol, $14 \alpha, 18 \alpha$ - [4-methyl, 3-oxo-[1-oxa -4- azabutane-1, 4-diyl], diacetate & $\mathrm{C}_{28} \mathrm{H}_{43} \mathrm{NO}_{6}$ & 489 \\
\hline 7 & 1 - monolinoleoglycerol trimethylsilyl ether & $\mathrm{C}_{27} \mathrm{H}_{54} \mathrm{O}_{4} \mathrm{Si}_{2}$ & 498 \\
\hline 8 & 17 - [1,5-dimethylhexyl] - 10,13-dimethyl $1-3$ - sstrylhexadecahydrocyclopenta [a] phenathren -2 - one & $\mathrm{C}_{35} \mathrm{H}_{52} \mathrm{O}$ & 488 \\
\hline
\end{tabular}

Table 3. Mineral concentration ( $\mathrm{mg} / \mathrm{gm}$ ) of thorn apple [55].

\begin{tabular}{|c|c|c|c|c|}
\hline SR. NO & MINERAL & SEED COAT & SEEDS & WHOLE SEEDS \\
\hline 1 & Magnesium & 399.20 & 344.07 & 307.94 \\
\hline 2 & Calcium & 57.00 & 426.50 & 295.10 \\
\hline 3 & Lead & 0.32 & 0.29 & 0.95 \\
\hline 4 & Chromium & 0.60 & 0.60 & 2.85 \\
\hline 5 & Iron & 6.92 & 3.93 & 5.63 \\
\hline 6 & Copper & 10.36 & 6.22 & 8.04 \\
\hline 7 & Manganese & 5.13 & 4.11 & 8.49 \\
\hline 8 & Zinc & 8.26 & 3.23 & 0.51 \\
\hline 9 & Phosphorus & 190.00 & 275.00 & 220.00 \\
\hline 10 & Potassium & 1.93 & 2.04 & 2.50 \\
\hline 11 & Sodium & 2.02 & 2.86 & 2.50 \\
\hline
\end{tabular}




\begin{tabular}{lll}
\hline SR. NO & NAME OF AMINO ACIDS & CONTENT IN JIMSON WEED \\
\hline 1 & Aspartic acid & 7.74 \\
2 & Threonine & 3.14 \\
3 & Serine & 4.03 \\
4 & Glutamine & 13.05 \\
5 & Proline & 3.32 \\
6 & Glycine & 3.87 \\
7 & Alanine & 3.51 \\
8 & Valine & 3.62 \\
9 & Cysteine & 2.00 \\
10 & Methionine & 1.38 \\
11 & Isoleucine & 3.22 \\
12 & Leucine & 5.31 \\
13 & Tyrosine & 2.55 \\
14 & Phenylalanine & 3.47 \\
15 & Histidine & 1.84 \\
16 & Lysine & 3.19 \\
17 & Arginine & 6.54 \\
18 & Tryptophan & 0.51 \\
\hline
\end{tabular}

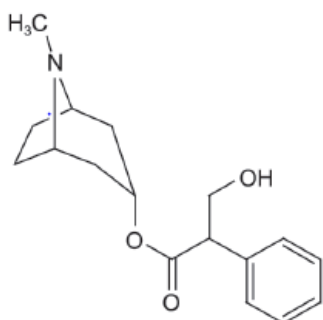

Hyoscyamine<smiles>COc1cc2ccc(=O)oc2cc1OC1OC(CO)C(O)C(O)C1O</smiles><smiles>CN1CCCC1CC(=O)CC1CCCN1C</smiles>

Cuscohygrine

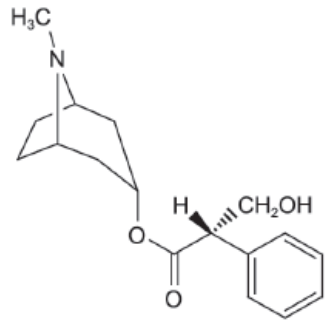

Atropine

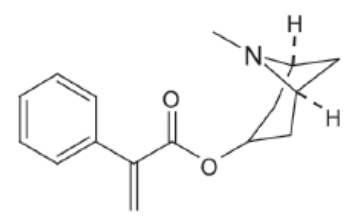

Atropamine<smiles>O=c1ccc2cc(O)c(O)cc2o1</smiles>

Esculetin

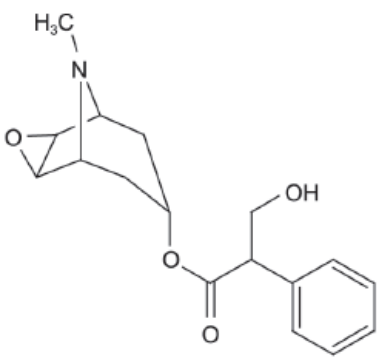

Hyoscine

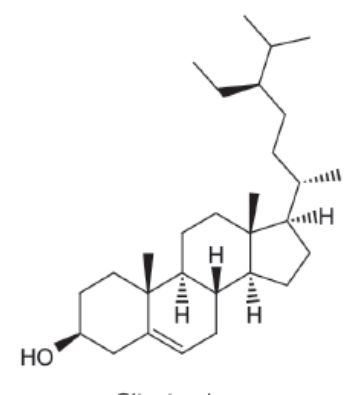

Sitosterol

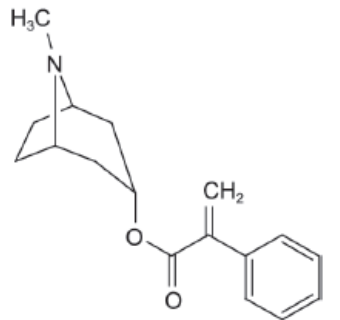

Apoatropine<smiles>C[C@H]1[C@@H](CO)O[C@@H](O[C@@H]2[C@@H](O)O[C@H](CO)[C@@H](O)[C@H]2O)[C@H](O)[C@H]1O</smiles>

Sophorose<smiles>O=C(/C=C/c1ccc(O)c(O)c1)OC1C(O)C2CC(O)(C(=O)O)C(O)C1O2</smiles>

Chlorgenic acid<smiles>C/C=C(\C)C(=O)OC1CC2C(O)C(C1)N(C)C2O</smiles>

Meteloidine

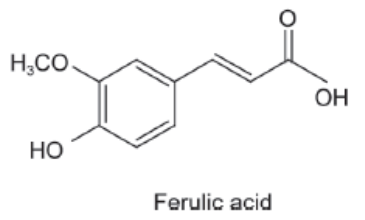

Figure 1. Various important phytochemicals found in Datura stramonium [6, 9, 40]. 


\section{Pharmacology}

\subsection{Anti-asthmatic Activity}

Datura stramonium was studied with respect to asthma treatment and possible effects on prenatal development. When a mother will use this plant for asthma treatment then the fetus will be exposed to it, and this plant will cause a continuous release of acetylcholine which results in desensitization of narcotic receptors, this could ultimately causes permanent damage to the fetus. Therefore it is concluded that this African herbal remedy should be used carefully during pregnancy [60].

\subsection{Antimicrobial Activity}

The extracts prepared from leaves and branches of jimson weed exhibit anti-microbial activities. The methanolic extracts of datura showed the antimicrobial activity against Gram positive bacteria. A very little antimicrobial activity was also observed against Escherichia coli and Pseudomonas aeruginosa [78]. When the combined crude ethanolic extracts of Datura stramonium along with Terminalia arjuna, Withania somnifera were analysed for the antibacterial and antifungal activities, a potential antimicrobial activity was observed against Staphylococcus aureus, Bacillus subtilus, Escherichia coli, Klebsiella pneumonia, Micrococcus luteus and Candida albicans [23]. The petroleum ether extracts of the plant have antimicrobial activities against E. coli and Trachystemon orientalis [70].

\subsection{Anti-rheumatic Activity}

The infusion prepared from stem, branches and leaves exhibits anti- rheumatic potential [40].

\subsection{Antibacterial Activity}

The leaf extracts of Datura stramonium show antibacterial activity against various strains of bacteria including Klebsiela pnuomenae, Staphylococcus aureus, Escherichia coli, Gram positive and Gram negative bacteria [66]. It is reported that higher concentrations of ethanolic leaf extracts are required for antibacterial activity against Klebsiela pnuomenae, Staphylococcus aureus, Escherichia coli to inhibit the growth. The antibacterial substance retard the formation of peptidoglycan and cells become died due to osmotic shocks. Datura stramonium exhibited a very significant antimicrobial activity against Bacillus thuringiensis and Agrobacterium tumefacians with the zone of inhibition of $16 \mathrm{~mm}$ and $19 \mathrm{~mm}$ [17]. The antibacterial activity of methanolic extracts of thorn apple seeds reveals that it is very active against Gram positive as well as Gram negative bacteria. These extracts show highest zone of inhibition $(20 \mathrm{~mm})$ against $E$. coli followed by $(17.50 \mathrm{~mm})$ zone of inhibition against $S$. aureus (16 mm) zone of inhibition against $P$. aeruginosa and lowest zone of inhibition (15 mm) against B. subtili [87].

\subsection{Nematicidal Activity}

The leaf extracts of $D$. stramonium exhibits very efficient nematicidal activity [71].

\subsection{Antifungal Activity}

A concoction prepared from D. stramonium, Azadirachta indica, Calotropis giganta, cow manure methanol and water has the strong antifungal activity against Fusarium magniferae [83]. The extracts obtained from leaves and branches of jimson weed exhibit antifungal properties. Datura stramonium exhibited very high antifungal activity against Aspergillus flavus [25].

The anti-fungal activity was observed against the Fusarium oxysporium (the fungal pathogen of pigeon pea plant) when the leaf extracts of eight plants including Datura stramonium, Hyptis sauveolens, Withania somnifera, Lawsonia inermis, Adhotoda zylanica was applied. The ethanolic extracts of these plants both in vivo and in vitro showed the inhibition of spore formation and growth of the pathogen [39].

\subsection{Anticancer Activity}

Various human cancer cells derived from breast (MDA-MB231), head, neck (FaDu) and lungs (A549) were exposed to aqueous extracts of $D$. stramonium for 24-48 hours and parameters of clonogenic cell and oxidative stress were also accounted. It was observed that cancer cell lines were sensitive to cell killing induced by extracts of Datura with some viability of $(p<0.05)[2]$.

\subsection{Antitumor Activity}

The endophytic fungi was separated from jimson weed and MTT assay was used on human gastric tumor cell line BGC- 823 to test the antitumor activity and the result was $100 \%$ growth inhibition. Agglutin (DSA lectin) isolated from Datura stramonium caused differentiation of C6 glioma cells which was irreversible. DSA also stalled the growth of four human glial tumor cells [23].

\subsection{Antioxidant Activity}

Flavonoids are polyphonic compounds. The content of flavonoids in the methanolic extracts of Datura stramonium was between $23.15-63.3 \mathrm{mg} / \mathrm{g}$. It was observed that they have properties of free radical scavenging, inhibition of hydrolytic oxidative enzymes and they also exhibit anti-inflammatory activity and their role in human health care and nutrition is significant $[47,62]$. The methanolic extracts can decrease the activity of DPPH free radicals just like Gallic acid which is a standard antioxidant [87]. The aqueous extract of Datura stramonium has more potent antioxidant activity as compared to organic extract [24].

\subsection{Vibriocidal Activity}

Organic solvent and aqueous extracts of different parts of the six medicinal plants was analyzed against the strain of Vibrio cholera for the treatment of cholera and gastrointestinal diseases. The results revealed that just like other medicinal plants $D$. stramonium can also be served as broad spectrum 
vibriocidal agent [71].

\section{Various Uses of Datura Stramonium}

\subsection{Traditional Uses of Datura Stramonium}

Jimson weed is used to cure the people having deafness, soothe insomniacs and to release the heat during fever. The plant is found in a 4,000 years old painting which indicated that it was used by the Huichol Indian along with peyote to converse the spiritual world. It is used in Delphi by the priests of Apollo to help them in their divination. In American medical journal it is mentioned that Datura stramonium is one of the best remedies for hydrophobia and there is other medicine having better results as compare to this plant. Datura and cannabis are used in combined form as smoke because it burns very easily [7]. British soldiers use it to treat respiratory problems. It is also used for the treatment of various diseases such as motion sickness, nausea and dizziness. It is used as an analgesic for bone setting. It is an important drug with respect to asthma treatment [44]. And for this purpose the leaves of the plant are smoked in cigarette or pipe. In India the plant is utilized in the various ethno veterinary practices by the Gujjar community. In Ethiopia students used it to increase their imagination power and to make their mind more receptive to leaning. The plant is used in ointments as craft witch in Europe. Many European countries use its seeds to brew beer. The various tribes of Mexico such as Opata and Seri use the plant non-religious rituals. The growing Datura The plant is known as Yangjinhua in China and the Chinese people use it in the treatment of various diseases such as asthma, pain, rheumatism convulsions [39]. The oil obtained by crushing the leaves of Datura stramonium is used for skin diseases, headache and dandruff and its stems and stalks are chewed for treatment of toothache and respiratory disorders in Kashmir valley [38]. The traditional uses of Datura stramonium in various parts of the world are listed in the table:

Table 5. Traditional uses of datura stramonium in different countries.

\begin{tabular}{llll}
\hline SR. NO & COUNTRIES & TRADITIONAL USES & REFRENCES \\
\hline 1. & Ethiopia & It is used for wound treatment against wound causing bacteria & {$[78]$} \\
2. & Rwanda & It is used for acaricidal activity & {$[61]$} \\
3. & Pakistan & Green leaves are used for softening the boils. Fruit juice is used for earache & {$[72]$} \\
4. & India & Fruit is burned and ash is used for bronchitis and asthma & {$[70]$} \\
5. & Bulgaria & It is used as anti-asthmatic, spasmolytic and antiviral remedy & {$[41]$} \\
6. & Japan & It is used to treat brain tumor. & {$[23]$} \\
7. & Spain & Leaves are used to treat spleen diseases. & {$[70]$} \\
8. & China & It is used during surgery as anaesthesia. & {$[23]$} \\
9. & Nepal & The plant is utilized in the various ethno veterinary practices. & {$[61]$} \\
\hline
\end{tabular}

\subsection{Medicinal Uses}

Extracts of Datura stramonium are prepared various solvents including ethyl acetate, acetone, chloroform, dichloromethane, methanol and ethanol for medicinal purposes [52].

\subsubsection{Medicinal Uses of Leaves of Datura Stramonium}

The leaves are used for treatment of pain and for this purpose the roasted leaves are applied on the affected area of body. They are very effective to cure headache, earache the pain due to hemorrhoids and neuralgia. They are used in mind altering drugs because of the presence of scopolamine and hyoscymine. The problem of arthritis (rheumatism and gout) can be overcome by the treatment with vapors of the leaves infusion. The smoke of the burning leaves is used to cure bronchitis [16]. The leaves are used as repellents against mites and mosquito. It is a good remedy for heart problems including palpitation and hypertension. The leaves are used as poultice to overcome boils. It is very much effective for treatment of whooping cough and spasm of bladder the leaves of Datura along with tobacco leaves are used as anodyne. It can also be used to cure rattlesnake bite, swellings, sprains and tumors. It relieves the pain of sciatica and certain medicinal effect is also observed for Parkinson's disease [37, 72].

\subsubsection{Medicinal Uses of Seeds of Datura stramonium}

The oil obtained from Datura is good stimulant for hair growth and can cure baldness. The fistules and abscesses are also alleviated by jimson weed seeds. Seeds of Datura have anthelmintic, analgesic and anti-inflammatory properties and therefore they are used to relieve toothache, fever due to inflammation and intestinal and stomach pain due to worms [32].

\subsubsection{Protection in Organophosphate Toxicity}

The terrorists use the organophosphate nerve agent and for the treatment of it atropine is required. For such treatment the hospital's entire atropine will be even insufficient. The plant jimson weed possesses atropine and it can be obtained simply by boiling the crushed seeds of the plant. So Datura stramonium could be used to cope up with organophosphate toxicity and it increases the survival chances [80].

\subsubsection{Tropane Alkaloids as Essential Medicine}

Species included in Datura genus i.e. D. stramonium, D. tatula and $D$. innoxia produce tropane alkaloids and these species are cultivated for their atropine, hyoscyamine, and scopolamine content because of their impact on human nervous system and they are used to treat neurological problems. Secondary metabolites obtained from plants specifically hyoscyamine (HS) exhibit vital role in stress adaptation. Harfi et al., established 343 independent hairy roots (HRs) lines of Datura and studied the production of hyoscyamine (HS). The results of GC/MS screening showed the production of 13 alkaloids [35]. 
Srinivasan et al., engineered yeast (Saccharomyces cerevisiae) strains for de novo production of tropine that is known as a key intermediate in the biosynthetic pathway of medicinal tropane alkaloids and this effort would contribute to industrial fermentation of medicinal TAs [76].

\section{Biotechnological Aspects}

\subsection{Biodiesel Preparation}

There is the worldwide scenario of increasing energy demand with increasing population trend. Witte et al., reported that in comparison to Jatrpha curcus beef tallow biodiesel the Datura stramonium oil's biodiesel has best kinetic viscosity [89]. Ashutosh investigated Datura Stramonium biodiesel and he reported that if pure Datura stramonium plant seeds oil is directly used in engine that would be ultimately ejected by converting it into biodiesel through trans-esterification, we can observe more viscosity consistency. Beside that its calorific values and cetane numbers were also same as that of diesel fuel [4].

\subsection{Bioremediation}

The plant is also used in bioremediation as it removes 2, 4, 6-trinitrotoluene (TNT) from explosive waste sites and convert it into other forms by nitroreduction [79].

Datura plant extracts are effective in reducing the toxicity of cypermethrin pesticide [14].

\subsection{Biocontrol}

\subsubsection{In Vitro Acaricidal and Oviposition Deterrent Properties}

The combined leaf extracts of Datura stramonium were applied against acaricide susceptible (IVRI-I line) Semicarpus anacardium and resistant (IVRI-I line) Rhiphicephalus microplus and they inhibited the growth [46]. The ethanol extracts of leaves and seeds of Datura stramonium were investigated for acaricidal, repellent and oviposition deterrent properties against adult two-spotted spider mites under laboratory conditions. The extracts of leaf and seed were applied in 167.25 and $145.75 \mathrm{~g} / \mathrm{L}$ concentrations respectively (using a Petri leaf disc-Spray tower method) and they caused $98 \%$ and $25 \%$ mortality among spider mite adults after 48 hours. So this result suggests that Datura stramonium can be used to control the two-spotted spider mites $[46,48]$.

\subsubsection{Larvicidal and Mosquito Repellent Activities}

The ethanolic exracts leaves of Datura stramonium were examined for larvicidal and mosquito repellent activities against Aedesaegypti, Anopheles stephensi and Culexquinquefasciatus. For larvicidal activity the LD50 values were found to be $86.25,16.07$ and $6.25 \mathrm{mg} / \mathrm{L}$ against Aedesaegypti, Anopheles stephensi and Culex quinquefasciatus respectively. These extracts provided complete mosquito repellency of 2.7, 71.7 and $117.7 \mathrm{~min}$ against Aedesaegypti, Anopheles stephensi and Culex quinquefasciatus at higher concentration. Datura stramonium exhibits significant larvicidal effects against Tribolium castaneum by reducing the growth rate and food consumption [37]. The ethanolic extracts of Datura stramonium exhibit significant larvicidal and mosquito repellent activities against Aedes aegypti, Anopheles stephensi and Culex quinquefasciatus [12].

\subsubsection{Insectividal Activity}

The extracts obtained from the powdered leaves, stem and seeds of Datura stramonium were used to check their ability to control the stored products from attack of Callosobruchus maculates and the results revealed that with the increase of concentration the mortality rate is increased [37].

\subsubsection{Reservoir of Virus and Whiteflies}

Tomato severe rugose virus (ToSRV) is very significant begomovirus whose transmission is carried out by whitefly Bemisia tabaci in tomato crops. Gorayeb et al., evaluated the role of Datura stramonium as alternative host of ToSRV and found that $D$. stramonium was mostly a good host for whitefly reproduction. As a result of viral infection improved performance of Bemisia tabaci Mediterranean (MED) cryptic species on host plant was also observed. It is concluded that Jimson weed has significant value for the pathosystem and its control must be encompassed in management practices [30].

\subsection{Callus Induction}

Callus induction and regeneration efficiency can be enhanced from embryo culture of Datura stramonium by adjusting carbon sources and concentration [3].

\subsection{Beverage Industry}

Datura stramonium is used in alcoholic beverages to increase the intoxication [37].

\subsection{Allelopathic Potential of Essential Oils from Datura Stramonium}

The chemical composition of essential oils in Jimson weed revealed that they contain sterols and its derivatives, $5 \alpha$ ergosta-7, 22-dien -3ß-ol (16.53\%), 3-hydroxycholestan - 5 methyl-acetate $(14.97 \%), 26,26$ dimethyl-5, 24 (28) ergostadien-3 $\beta$-ol (10.39\%). Their phytotoxic activity was analayzed in five cultivated crops and they retarded the growth of lettuce, radish, maize, cucumber and common beans. So it is concluded that Datura stramonium releases some allelochemicals in environment (both water solube and volatile forms) to inhibit the growth of other plant species [90]. Germination and development of roots of Linum usitatissimum is inhibited by leaf and seed extracts of Jimson weed [53].

\section{Toxicity}

The extracts of the plant are potentionally poisonous and random use can cause restlessness and severe poisoning can lead to death. Since the earliest record of history the hallucinogenic properties of Datura stramonium are known [10]. Tropane alkaloids include atropine (dl-hyoscyamine) 
and scopolamine (i- hyoscine) [23]. Atropine and scopolamine act as the depressant of central nervous system and they affect the muscarinic cholinergic receptors [20]. Many cases of suicide attempts by eating and chewing of Datura have been reported. It is very toxic plant because of the presence of toxic tropane alkaloids. Once soldiers ate this plant in salad in the region of Jamestown (Virginia) in 1676 and they got died because of the poisoning of the plant and for that reason the plant got its name as Jimson weed. The plant has very bitter taste and the animals usually don't eat it. But if food resources are inadequate the cattle, sheep, goat and horses consume it and get poisoned. In fatal cases the body temperature become very abnormal, it may lead to coma and the ultimate result could be death. Toxicity symptoms include nervousness, bloat anorexia, tenesmus, rumen atony, tremors, excitability and even death in most severe cases [50]. The plant is very harmful for cattle, human, horses, sheeps, pigs, mules and chicken. Jimson weed has constrained medicinal uses. Datura seeds are many times accidently or intentionally ingested by human beings [86].

\subsection{Datura Stramonium Poisoning in Horses}

In horses intoxication with thorn apple results in hyperthermia, tachycardia, polypnoea with dispnoea, acute gastric dilation, secondary intestinal gas accumulation, mydriasis, dry mucosae, lack of thirst, complete refusal of feed, urination and defecation [10].

\subsection{Toxicological Evaluation of Datura Stramonium in Rats}

A sub-chronic feeding study of 90 days was carried out in male and female rats by providing diet comprising of $0.5,1.58$ and $5.0 \%$ jimson weed seeds. The seeds contain $2.70 \mathrm{mg}$ of atropine $0.66 \mathrm{mg}$ of scopolamine per gram. The jimson weed seeds produced certain effects including decrease in body weight, serum albumin, serum calcium and increase in testes and liver weight, serum alkaline phosphate and blood urea nitrogen. There were more obvious affects in female rats as compared to male rats, as females showed decrease in serum proteins and cholesterol and increase in serum glutamic-pyruvic transaminase and chloride, red blood cells and hemoglobin. There were not seen any histological lesions at $0.5 \%$ concentration of jimson weed. More adverse physiological changes were observed at $0.5 \%$ concentration of jimson weed in rats [19].

\section{Conclusion}

Plants are very important for pharmacological research and drug development as their bioactive constituents can directly be used as therapeutic agents and precursors for drug development. This paper has directed towards various interesting findings of medicinal value of Datura stramonium. Apart from its toxicity and ornamental value it possesses various phytochemicals which prove it as potent chemotherapeutic agent. Various parts of the plant are used in Ayurveda to treat human ailments. Present review gives us broad information about the bioactive constituents, ethnopharmacology along with scientifically claimed medicinal uses of Datura stramonium. The plant shows various important pharmacological activities due to the presence of active chemical compounds.

The findings of this paper would be helpful for the development of new agents for medical application (i.e. especially drugs for asthma, diabetes, epilepsy) and agro-industries based on natural products derived from plants. The plant can be used as a biocontrol agent because of its insecticidal, fungicidal activities and can also be used in bioremediation. It can also be used for biodiesel preparation. Extracts of Datura could be of high value in grain storage $C$. maculatus especially when plants are available to farmers with little resources to meet the high cost of pesticides.

As it is potentially toxic plant, its adverse effects can be extremely harmful. Therefore despite of beneficial aspects, the risk - benefit ratio should always be taken into consideration before using. It should be used very carefully after the proper consultation of the specialized person and females using it for asthma treatment should stop its use during pregnancy. There is a need of further investigation and quantification of phytoconstituents and pharmacological profile.

This information will play an important role to understand pharmacological, medicinal and biotechnological aspects of this plant and will also direct the future research.

\section{References}

[1] Abdollahi, M., H. Karimpour and H. P. Monsef-esfehani. 2003. Antinociceptive effects of Teucrium polium L. total extracts and essential oil in mouse writhing test. Pharmacology. 3 (8): 21-26.

[2] Ahmed, I., M. Y. Abdullah, N. H. Mustafa, E. Y. Qnais and F. A. Abdullah. 2009. Datura aqueous leaf extracts enhances cytotoxicity, metabolic oxidative stress on different human cancer cells. Journal of Biological Sciences. 2 (1): 9-14.

[3] Altameme, H. J., I. H. Hameed and M. A. Kareem. 2015. Analysis of alkaloid phytochemical compounds in the ethanolic extract of Datura stramonium and evaluation of antimicrobial activity. African Journal of Botany. 14 (19): 1668-1674.

[4] Ashutosh G. 2020. Experimental investigation of Datura Stramonium biodiesel. International Journal of Advance Research, Ideas and Innovations in Technology, 6 (2).

[5] Bazaoui, A. E., M. A. Bellimam and A. Soulaymani. 2011. Nine new tropane alkaloids from Datura stramonium L. identified by GC-MS. Fitoterapia. 82 (2): 193-197.

[6] Berkov, S., R. Zaved and T. Douncheva. 2006. Alkaloid patterns in some varieties of Datura stramonium. Filoterapia. 77: 179-182.

[7] Bellakhdar, J. 1997. La pharmacopee marcaine traditionnelle. Saint-etime, Iberis press, pp: 494-496.

[8] Berkov, S., A. Parlov, P. Kovacheva, P. Stanimirora and S. Philipov. 2003. Alkaloid spectrum in diploid and tetraploid root cultures of Datura stramonium. Z Naturfrosch C. 58: 42-46.

[9] Biren, S. 2009. Textbook of pharmacognosy and phytochemistry. Elslevier-health sciences. pp: 193. 
[10] Binev, R., I. Valchev and J. Nikolov. 2006. Clinical and pathological studies of Jimson weed poisoning in horses. Turkia Journal of Sciences. 4 (3): 56-63.

[11] Blossey, J. W., H. Budzikiwics, M. Ohashi, G. Fodor and C. Djerassi. 1964. Mass spectrometry in structural and sterochemical problems-XXXIX tropanealkaloids. Tetrahedron. 20: 585-595.

[12] Couladis, M., O. Tzakon, E. Verykokidou and C. Harvala. 2003 Screening of some Greek aromatic plants for antioxidant activity. Phytotherapy Research. 17: 194-195.

[13] Clapham, A. R., T. G. Tutin and D. M. Moore. 1987. Flora of British Isles, $3^{\text {rd }}$ edition. Cambridge university press, Cambridge UK.

[14] Das, B. K. Mukherjee, S. C. 2003. Toxicity of cypermethrin toxin in Labeo rohita fingerlings: biochemical, enzymatic, haematological consequences. Comp biochem physio part $\mathrm{c}$ toxicol pharmacol. 134 (1), pp: 109-121.

[15] Das, S., P. Kumar and S. P. Basu. 2012. Review article on phytoconstituents and therapeutic potentials of Datura stramonium. J. Drug. Del. Therap. 2: 4-7.

[16] Dessanges, J. F. 2001. A history of nebulization. J. Aerosol. Med. 14 (1): 65-71.

[17] Deshmukh, A. S., P. D. Shelke, K. S. Palekar, S. D. Pawar and H. S. Shindes. 2015. Antimicrobial investigations of Datura stramonium leaf extracts against different microorganisms. IOSR Journal of environmental science, toxicology and food technology. 9 (9): 17-19.

[18] Doncheva, T., S. Philipov and N. Kostova. 2004. Alkaloids of Datura stramonium L. competes Rendus de 'I' academic Bulgare de Sciences. 57: 41-44.

[19] Dugan, G. M., M. R. Gumbmann and M. Friedmann. 1989. Toxicological evaluation of Jimson weed seed. Food and Chemical Toxicology. 27 (8): 501-510.

[20] Ekanem, P. E., R. Ekanem and K. Gaim. 2016. Histological patterns of neurodegeneration of frontal cortex neurons in Datura stramonium treated Wistar Rats. Journal of Behavioral and Brain Sciences. 6: 85-92.

[21] Evan, W. and J. Lampard. 1972. Alkaloids of Datura suoveolens. Phytochemistry. 11: 3293-3298.

[22] Evans, W. C. and K. P. Ramsey. 1981. Tropane alkaloids from anthocercis and anthotroche. Phytochemistry. 20: 497-499.

[23] Friedman, M. and C. E. Levin. 1989. Composition of Jimson Weed seed. Journal of agriculture and food chemistry. 37: 998-1005.

[24] Gachande, B. D. and E. M. Khillare. 2013. Invitro evaluation of Datura species for potential antimicrobial activity. Biosci Discov. 4 (1): 78-81.

[25] Ganesan, K., S. K. P. Nair, H. G. Azaleusor, N. Letha and S. B. Ghani. 2016. Preliminary phytochemical screening and invitro antioxidant activity of Datura stramonium collected from Jimmah, South West Ethiopia. International Journal of Pharma and Bio Sciences. 7 (1): 261-266.

[26] Ghaida, J. M., H. H. Imad and K. A. Sabreen. 2016. Study of secondary metabolites produced by Aspergillus flavus and evaluation of antifungal and antibacterial activity. African Journal of Biotechnology. 2 (6): 18-25.
[27] Gharaibeh, M. N., H. H. Elayan and A. S. Salhab. 1998. Hypoglycemic effects of Teucrium polium. Journal of ethnopharmacology. 24: 93-99.

[28] Ghani, A. and A. M. Pindiga. 1985. A comparative pharmacognostic study of two Nigerian Datura species. Nigerian jour of pharmaceutical sciences. pp: 31-36.

[29] Gillard, J. W, H. M. Leon and N. W Preston. 1797. Alkaloid of Belledena montana family Potaceae. Australian Journal of chemistry. 32: 2071-2082.

[30] Gorayeb, Eduardo S., Bello, Vinicius H., Cruciol, Giovana Carolina D., Watanabe, Luís Fernando M., Dovigo, Leonardo H., Sartori, Maria Márcia P., Krause-Sakate, Renate. (2020). Evaluation of Datura stramonium and Nicandra physaloides as reservoirs of tomato severe rugose virus and whiteflies. Plant Pathology, 69 (3), 569-575. doi: 10.1111/ppa.13139.

[31] Gupta, D. P. 2008. The herb, habitat, morphology and pharmacognosy of most important medicinal plants. Printwell Offset publishers, Madhya Pardesh, $1^{\text {st }}$ edition, pp: 185.

[32] Gray, I., A. Strafford, K. Anna, B. Jager and V. S. Johannes. 2005. Activity of traditional South African sedative and potentially CNS acting plants of Gabba-benzodiazapine acceptor assay. J. Ethnopharm. pp: 201-215.

[33] Hanson, C. G. and J. L. Mason. 1985. Bird seed aliens in Britain. Watsonia. pp: 237-252.

[34] Habib, A., M. Mohammed, R. Fahimeh and H. H. Muhammad. 2011. Bioactivities of Jimson weed extracts of Datura stramonium against Tribolium casteneum. Turkish Journal of Agriculture and Forestry. 35: 623-629.

[35] Harfi, Boualem, Khelifi, Lakhdar, Khelifi-Slaoui, Majda, Assaf-Ducrocq, Corinne, \& Gontier, Eric. 2018. Tropane alkaloids GC/MS analysis and low dose elicitors' effects on hyoscyamine biosynthetic pathway in hairy roots of Algerian Datura species. Scientific Reports, 8 (1), 17951. doi: 10.1038/s41598-018-36625-4.

[36] Hong L., Z. Guo, K. Huang, S. Wei, B. Liu, S. Meng, C. Long. 2015. Ethnobotanical study on medicinal plants used by Maonan people in China. Journal of ethnobiology and ethnomedicine. 11 (32).

[37] Kamal, M., M. Adnan, W. Murad, A. Bibi, A. Tariq, H. Rehman and Z. K. Shinwari. 2016. Anti-rheumatic potential of Pakistani medicinal plants: A review. Pak. J. Bot., 48 (1): 399-413.

[38] Khan, S., A. Kamili and R. C. Gupta. 2016. Economic and medicinal properties of medicinal plants found in Kashmir Himalaya. Journal of Medicinal Plants Studies. 4 (3): 38-44.

[39] Khandare, K. R. Salve, S. B. 2011. Management of wilt of pigeon pea (Cajanus cajan L.) through biopesticide (leaf extracts). Int Ref Res J. 2 (18). pp: 21-22.

[40] Ionkov, I., L. Witte and H. A. Alfermann. 1994. Spectrum of tropane alkaloids in transformed roots of Datura innoxia and Hyoscyamus cultivated in vitro. Planta Medica. pp: 60.

[41] Ivanov, I. and S. Nikalov. 1988. Tropane alkaloids in the pharmacognosy medicinal. Fizkuttura, Sofia. 351-355.

[42] Jeralg, E. and S. Edvin. 2007. Text book of pharmacognosy and phytochemistry. CBS publishers and distributors, Newdehli, $1^{\text {st }}$ edition, p: 224. 
[43] John, B. S. and S. Senthikumar. 2005. Antibacterial activity of Solanum incatum L. leaf extracts. Asian J. of Microb. Biotech. Environmental Sciences. 3: 65-66.

[44] Khan and Yadaba. 2010. Herbal remedies of asthma in Thoubal District of Manipur in North East India. Indian Journal of natural products and resources. 1 (1): 80-84.

[45] Kumar, V. P., S. Shashidra, M. M. Kumar and B. Y Sridhara. 2001. Cytoprotective role of Datura species against gentamicin-induced kidney cell (vero) cells damage in vitro. Fitoterapia. 72: 481-486.

[46] Kumral, N. A., C. Sultan, C. Yalcin. 2010. Acaricidal and oviposition deterrent properties of Datura stramonium against adult Tatranychus utricae (Koch). Journal of Pest Science. 83: 173-180.

[47] Kumar, P. S., S. Sucheta, V. S. Deepa, P. Selvamani and S. Latha. 2008. Antioxidative activity in some selected Indian medicinal plants. African Journal of Biotechnology. 7 (12): 1826-1828.

[48] Kurnal, N. A. and S. C. C. Yalcin. 2009. Acaricidal, repellent and oviposition deterrent activities of Datura stramonium L. against adult Tetranychus utricae (Koch). J. Pest Sci. 14: 54-57.

[49] Lounasmaa, M. and T. Taminnen. 1993. The tropane alkaloids, in the alkaloids. The alkaloids of academic press, New York. 44: $1-100$.

[50] Maibam, R. D., M. Bawari, S. B. Paul and G. D. Sharma. 2011. Neurotoxic and medicinal properties of Datura stramonium L. - Review. Assam university journal of science and technology biological and environmental sciences. 7: 139-144.

[51] Mandal, B. K. and A. Shah. 2013. A review on pharmacological actions and use of plant Datura. Univer $\mathrm{J}$ Pharm. 2 (2): 47-51.

[52] Mekonen, T., M. Giday, E. Kelbessa, 2015. Ethnobotanical study of home garden plants in Sabeta-Awas District of Oromia region in Ethiopia to assess use, species diversity and management practices. Journal of ethnobiology and ethnomedicine, 11 (64).

[53] Muller, K. and H. A Arfmann. 1987. Investigation of alkaloid pattern of Datura stramonium plants by capillary gas-liquid chromatography mass-spestrometry. Planta Maedica. 53: 192-197.

[54] Oudhia, P., R. S. Tripathi. 1998. Allelopathic potential of Datura stramonium L. Crop. Res. 16 (1): 37-40.

[55] Oseni, O. A., C. O. Olarinoye and I. A. Amoo. 2011. Studies on chemical composition and functional properties of thorn apple. African Journal of Food Sciences. 5 (2): 40-44.

[56] Philipov, S. and S. Berkov. 2002. GC-MS investigation of tropane alkaloids in Datura stramonium. Naturforsch C. 57: 559-561.

[57] Parr, A. J., J. Payne, J. Eagles, B. T. Champan, R. T. Robins and M. J. Rhodes. 1990. Variation in tropane alkaloids accumulation within the Solanaceae and strategies for its exploitation. Phytochemistry. 29: 2545-2550.

[58] Pawlowski, K., F. J. Kapeluszny, A. Kolasa and Z. Lycyk. 1967. Fertility of some species of ruderal weeds. Annales universitatis mariae curie-sklodowska lubin-polonia. 22 (15): 221-231.
[59] Preissel U. Preissel, H. G. 2002. Brugmansia and datura: angel's trumpets and thornapple. Buffalo NY: firefly books. pp: 106-129.

[60] Protorius, E. and J. Marx. 2006. Datura stramonium in asthma treatment and possible effects on prenatal development. Environ. Toxicol Pharm. 21 (3): 331-337.

[61] Puyvelde, V., L. I. Geysoen, F. X. Ayobangan, E. Hakizamungu and A. Nshimyimana, A. Kalisha. 1985. Science of medicinal plants of Ruanda for the acaricidal activity. Journal of Ethnopharmacology. 13: 209-215.

[62] Rasekh, H. R., M. J. Khushnood-mansourkhani and M. Kamalinejad, M. Tariq, A. M Angel, J. S. Mossa and M. S Alsaid. 1989. Anti-inflammatory activity of Teucrium polium. International Journal on Tissue reaction. 11: 185-188.

[63] Robins, R. G., A. G. Parr, J. Payne, N. J Walton and M. G. Rhodes. 1990. Factors regulating traopane alkaloids production in transformed culture of a Datura candida x Datura aurea hybrid. Planta. 181: 414-422.

[64] Radford, A. E., H. E. Ahles and C. R. Bell. 1964. Mannual of vascular Flora of Carolinas. University of North Carolina press, Chapel Hill. 3 (5): 188-195

[65] Robins, R. J., A. J. Pars. E. C Bent and J. C. Rhodes. 1991. Studies on the biosynthesis of tropane alkaloids in Datura stramonium transformed root cultures. Planta. 183: 185-195.

[66] Reddy, B. U. 2010. Enumeration of antibacterial activity of few medicinal plants by bioassay method. E. Journal of Chemistry. 7 (4): 1449-145.

[67] Sazada, S., V. Arti, A. R. Ayaz, J. Faraha and K. Mukesh. 2009. Preliminary phytochemical analysis of some important medicinal and aromatic plants. 3 (5): 188-195.

[68] Santh, R. T. 2006. Antibacterial activity of Adhatoda vasica leaf extracts. Asia j. Microbial. Biotech.

[69] Salisbury, E. J. 1961. Weeds and Aliens. New naturalist series, Collins, London.

[70] Sharma, M. C., S. Sharma. 2010. Phytochemical, preliminary pharmacognostical and antimicrobial activity of combined crude aqueous extracts. Int J. Microbial. Res. 1 (3): 166-170.

[71] Sharma, N. and P. C. Trivedi. 2002. Screening of leaf extracts of some plants for their nematicidal and fungicidal properties against Meloidogyne incognita and Fusarium oxysporium. Asian journal of experimental sciences. 16: 21-28. Sharma, J., R. M. Painuli and R. D. Goruv. 2010. Plants used by rural communities of District Shahjahanpur, Uterpardesh. Indian Journal of Traditional Knowledge. 9: 798-803.

[72] Shinwari, M. I. and M. A. Khan. 2000. Folk use of medicinal hills of Margalla Hills National park Islamabad. Journal of Ethnopharmacology. 69: 45-46.

[73] Singh, S. K. K. Saroj, U. J. Tirupathi, A. K Singh and R. H. Singh. 1998. An antimicrobial principles from Spheranthus indicus. Int J crude drug. 26: 235-239.

[74] Singh, H. B., R. S. Singh and I. S. Sandhu. 2003. Herbal medicines of Manipur. A colour encyclopedia, Daya publishing house Dehli. pp: 15.

[75] Soni, P., A. A. Siddiqui, V. Soni. 2012. Pharmacological properties of Datura stramonium as a potential medicinal tree: An overview. Asian Pac. J. Trop. Biomed. 2: 1002-1008. 
[76] Srinivasan, Prashanth, and Smolke, Christina D. 2019. Engineering a microbial biosynthesis platform for de novo production of tropane alkaloids. Nature Communications, 10 (1), 3634. doi: 10.1038/s41467-019-11588-w.

[77] Stace, C. 1996. New flora of British Isles. Cambridge university press, Cambridge, UK, $2^{\text {nd }}$ edition. Environ. Sci. 8 (2): $287-289$.

[78] Takhi, D., M. Ouinten. 2011. Study of antimicrobial activity of secondary metabolites extracted from spontaneous plants from the areas of Laghouat, Algeria. Adv. Environm. Biol. 5 (2): 469-476.

[79] Taleb, A. 1995. Alore alustree des principales mauvaises des cultures du Gharb. pp: 294-295.

[80] Theodore, C. B. Jasan, C. Dallus, B. Malanie, O. 2004. Jimson weed extract as a protective agentin severe organophosphate toxicity. Acad Emerg Med. 11 (4). pp: 335-338.

[81] Toth, A., G. B. Benescsene and G. Balazs. 1997. Changes in field weeds in Hungary during the last 46 years. Proceedings of 1997 Brighton Conference - Weed. pp: 249-254.

[82] Toth, A., G. Benesc-Bardi and G. Balazs. 1999. Results of National weed survey in arable land during past 50 years in Hungary. Proceedings of 1997 Brighton Conference - Weed. pp: 805-810.

[83] Usha, K. B. Singh, P. Praseetha, N. Deepa, D. K. Agarwal, R.
Agarwal, A. Nagaraja. 2009. Antifungal activity of Datura stramonium Calaotropis gigantea and Azadirachta indica against Fusarium magniferae and malformation in mango. European Journal of plant pathology. 124: 637-657.

[84] Ventakesan, M., M. B. Vishwanathan and N. Ramesh. 2005. Antibacterial potential from Indian Suregada angustifolia. J. Ethnopharmacol. 99: 349-352.

[85] Vitale, A. A. and A. Acher. 1995. Alkaloids of Datura ferox from Argentina. Journal of Ethnopharmacology. 49 (2): 81-89.

[86] Weaver, S. E and S. I. Warwick. 1984. The biology of Canadian weeds. 64. Datura stramonium L. Canadian.

[87] Waza, S. A. P. Anthony and S. Dar. 2015. Phytochemical analysis, antioxidant and antimicrobial activities of methanolic extracts of Datura stramonium seeds. IJPSR. 6 (7): 3021-3026.

[88] Witt, A., Luke, Q., 2017. Guide to the naturalized and invasive plants of Eastern Africa, [ed. by Witt, A., Luke, Q.]. Wallingford, UK: CABI.vi $+601 \mathrm{pp}$.

[89] Witte, Muller K and Arfmann HA, Investigation of the alkaloid pattern of Datura innoxia plants by capillary gas-liquid chromatography mass spectrometry, Planta Medica. 53; 1987: 192-197.

[90] You. L. X. and S. J. Wang. 2011. Chemical composition and allelopathic potential of essential oil from Datura stramonium. Advanced Material Research. 2472-2475. 